\title{
STABILITAS pH DAN SUHU DAN BERAT MOLEKUL PEKTIN HIDROLASE EKSTRASELULER BAKTERI PEKTINOLITIK DALAM KLARIFIKASI JUS JERUK
}

\author{
pH STABILITY AND THERMOSTABILITY AND MOLECULAR WEIGHT OF \\ EXTRACELLULAR PECTIN HYDROLASE OF PECTINOLYTIC BACTERIA \\ ON CITRUS JUICE CLARIFICATION
}

\author{
Esti Widowati ${ }^{1)}$ Harijono $^{2)}$ Aji Sutrisno ${ }^{2)}$ \\ 1) Staf Pengajar Program Studi Ilmu dan Teknologi Pangan Fakultas Pertanian Universitas Sebelas Maret \\ 2) Staf Pengajar Jurusan Teknologi Hasil Pertanian Fakultas Teknologi Pertanian Universitas Brawijaya \\ Email : esti_widowati@yahoo.com
}

\section{ABSTRACT}

The aim of this research were to determine extracellular pectin hydrolase enzyme characters in citrus juice clarification (pH stability, thermostability and molecular weight) from pectinolytic bacteria. Isolate 15 was the isolate from dari citrus peel with incubation temperature at $37^{\circ} \mathrm{C}$ and isolate 19 and 21 from mix of citrus peel and soil with incubation temperature partially $50^{\circ} \mathrm{C}$ and $55^{\circ} \mathrm{C}$. Extracellular pectin hydrolase from isolate 15 stable at $\mathrm{pH} 3,0-4,0$ and at $\mathrm{pH} 3,0-5,0$ of isolate 19 and 21. These isolates inactive at $\mathrm{pH} 9,0$ at $50^{\circ} \mathrm{C}$. Extracellular pectin hydrolase from isolate 15,19 and 21 stable at $50^{\circ} \mathrm{C}$ at $\mathrm{pH} 7,0$ and inactive at $90^{\circ} \mathrm{C}$ at $\mathrm{pH}$ 7,0. Each enzyme from isolate 15, 19 and 21 had molecular weight partially 35,5 kDa, 34,5 kDa and 37,5 kDa.

Key words: Citrus juice clarification, Extracellular pectin hydrolase, Molecular weight, Pectinolytic bacteria, pH stability, Thermostability

\begin{abstract}
ABSTRAK
Penelitian ini bertujuan untuk menentukan karakter enzim pektin hidrolase ekstraseluler dalam klarifikasi jus jeruk dari isolat bakteri pektinolitik yaitu kestabilan enzim terhadap $\mathrm{pH}$ dan suhu dan berat molekul enzim. Isolat 15 diperoleh dari kulit jeruk yang dibusukkan dengan suhu inkubasi $37^{\circ} \mathrm{C}$ sedangkan isolat 19 dan 21 diperoleh dari kulit jeruk ditambah tanah kebun dengan suhu inkubasi masing-masing $50^{\circ} \mathrm{C}$ dan $55^{\circ} \mathrm{C}$. Enzim pektin hidrolase ekstraseluler isolat 15 stabil pada $\mathrm{pH}$ 3,0-4,0 sedangkan enzim pektin hidrolase ekstraseluler isolat 19 dan 21 stabil pada $\mathrm{pH} 3,0-5,0$. Ketiga enzim inaktif pada $\mathrm{pH} 9,0$ pada suhu inkubasi $50^{\circ} \mathrm{C}$. Enzim pektin hidrolase ekstraseluler isolat 15,19 dan 21 stabil pada suhu $30-50^{\circ} \mathrm{C}$ kemudian inaktif pada suhu $90^{\circ} \mathrm{C}$ pada $\mathrm{pH}$ 7,0. Enzim pektin hidrolase ekstraseluler isolat 15, 19 dan 21 masing-masing memiliki berat molekul
\end{abstract} sebesar 35,5 kDa; 34,5 kDa dan 37,5 kDa.

Kata Kunci : Bakteri pektinolitik, Berat molekul, Kestabilan pH, Kestabilan suhu, Klarifikasi jus jeruk, Pektin hidrolase ekstraseluler

\section{PENDAHULUAN}

Jus jeruk merupakan suspensi koloid dari pektin, gula, protein dan mineral. Molekul-molekul tersebut menyebabkan kekeruhan dan viskositas yang tinggi pada jus jeruk (Benitez and Lozano, 2006 dalam Widowati dkk, 2012). Pektin dalam jus jeruk dapat mempengaruhi warna dan citarasa (Croak and Corredig, 2006).

Klarifikasi jus jeruk dapat dilakukan dengan filtrasi atau sentrifugasi untuk mengendapkan pulp. Pektin larut air dalam jus jeruk masih menyebabkan kekeruhan dan dapat menyumbat pori membran filter sehingga menghambat proses klarifikasi (Pilnik and Voragen, 1993 dalam Widowati dkk, 2012). Oleh karena itu diperlukan enzim pektinase.

Mekanisme klarifikasi jus jeruk dengan keterlibatan enzim dilakukan dengan memperkecil molekul pektin menjadi senyawa pektat yang larut air sehingga viskositas jus menurun (Pilnik and Voragen, 1993; Koutchma, 2005), melalui mekanisme pengendapan agregat (de Man, 1997) dan mencegah pembentukan gel (Hidayat dkk, 2006).

Menurut deCarvalho et al.,(2006), proses klarifikasi jus jeruk yang melibatkan enzim biasanya berlangsung pada suhu $40^{\circ} \mathrm{C}-65^{\circ} \mathrm{C}$ pada $\mathrm{pH} 3,5-5,5$ selama $15-120$ menit. Oleh karena itu dalam penelitian ini dilakukan eksplorasi dan karakterisasi isolat termofolik dan enzim termostabil. 
Enzim pektinase untuk klarifikasi jus dapat diperoleh dari bakteri yang memiliki laju pertumbuhan sel yang cepat dan mudah dibiakkan pada kondisi nutrisi, suhu dan $\mathrm{pH}$ yang bervariasi. Isolat termostabil saat ini belum banyak dieksplorasi terutama dalam aplikasi industri yang menggunakan suhu tinggi.

Penelitian ini bertujuan untuk mengkarakterisasi enzim pektin hidrolase ekstraseluler dalam klarifikasi jus jeruk dari isolat bakteri pektinolitik yaitu kestabilan enzim terhadap $\mathrm{pH}$ dan suhu dan berat molekul enzim.

\section{METODE PENELITIAN}

\section{Penelitian Tahap I}

Produksi, Ekstraksi dan Pemurnian Enzim Pektin Hidrolase Ekstraseluler (Salvador et al., 2002; Rolinek, 2003 dalam Widowati dkk, 2012)

Produksi enzim ditentukan pada fase logaritma isolat. Penentuan kurva pertumbuhan bakteri dilakukan dengan penentuan panjang gelombang maksimum dan kurva standar isolat dalam media pektin cair. Kurva pertumbuhan dilakukan pada media pektin cair dengan agitasi $144 \mathrm{rpm}$ sesuai dengan suhu masing-masing isolat. Aktivitas enzim kasar diuji dengan metode DNS pada setiap titik pengambilan sampel kurva pertumbuhan. Kurva pertumbuhan isolat dan kurva aktivitas enzim kemudian digabungkan untuk penentuan hubungan antara jumlah sel dan fase pertumbuhan sel dengan aktivitas enzim.

Isolat bakteri yang telah mencapai fase logaritma kemudian diekstraksi dengan sentrifugasi pada kecepatan $6000 \mathrm{rpm} 4^{\circ} \mathrm{C}$ selama 15 menit. Supernatan dipresipitasi dengan fraksinasi ammonium sulfat $10-90 \%$. Sentrifugasi dilakukan pada kecepatan $12000 \mathrm{rpm}$ selama 10 menit $4^{\circ} \mathrm{C}$. Pellet ditambah dengan buffer asetat $0,05 \mathrm{M} \mathrm{pH}$ 5,2 (1:1). Uji aktivitas enzim kemudian dilakukan dengan metode DNS pada fase supernatan dan pellet.

Fase dengan aktivitas enzim tertinggi dimasukkan dalam kantung membran selophan untuk prosedur dialisis. Membran tersebut direndam selama 24 jam pada suhu $4^{\circ} \mathrm{C}$ dalam gelas beaker $600 \mathrm{ml}$ berisi $300 \mathrm{ml}$ buffer asetat $0,05 \mathrm{M} \mathrm{pH} \mathrm{5,2} \mathrm{yang} \mathrm{dilengkapi}$ magnetic stirer.

\section{Penelitian Tahap II}

Karakterisasi Enzim Pektin Hidrolase (Laemmli, 1970; Van Rijssel et al., 1993; Munoz and Ros, 1996; Wilson and Walker, 2004)

\section{Penentuan Kestabilan pH dan Suhu Enzim Pektin Hidrolase Ekstraseluler}

Kestabilan pH enzim dilakukan dengan $0,1 \mathrm{ml}$ enzim diinkubasi dalam 0,1 $\mathrm{ml}$ buffer sodium asetat $0,025 \mathrm{M} \mathrm{pH}$ $3,4,5,6,7,8,9$ dan 10 selama 30 menit pada suhu $50^{\circ} \mathrm{C}$.

Kestabilan suhu enzim dilakukan dengan $0,1 \mathrm{ml}$ diinkubasi dalam $0,1 \mathrm{ml}$

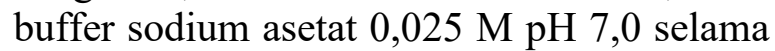
30 menit pada suhu $30,40,50,60,70,80$ dan $90^{\circ} \mathrm{C}$.

Uji aktivitas enzim pektin hirolase ekstraseluler didasarkan pada pengukuran gula reduksi yang dilepaskan. Penentuan gula reduksi dilakukan dengan metode DNS dengan asam D-galakturonat sebagai standar. Enzim sebanyak 0,1 $\mathrm{ml}$ dicampur dengan 0,9 $\mathrm{ml}$ media pereaksi $(0,7 \%$ pektin citrus ditambah buffer sodium asetat $0,025 \mathrm{M} \mathrm{pH}$ 4,8) dan diinkubasi pada suhu $37^{\circ} \mathrm{C}$ selama 30 menit. Sampel ditambah $1 \mathrm{ml}$ DNS kemudian dipanaskan selama 10 menit dalam air mendidih bersuhu $90^{\circ} \mathrm{C}$. Seluruh tabung reaksi didinginkan. Larutan K-NaTartrat $40 \%$ ditambahkan sebanyak $0,5 \mathrm{ml}$ dan dihomogenkan. Masing-masing sampel ditera pada panjang gelombang $540 \mathrm{~nm}$. Aktivitas enzim ditentukan dengan mengkonversikan nilai absorbansi asam Dgalakturonat dengan persamaan regresi linier kurva standar asam D-galakturonat 100 ppm.

Satu unit aktivitas enzim pektin hidrolase dinyatakan sebagai $1 \mu \mathrm{mol}$ gugus reduksi yang mampu dihidrolisis oleh enzim per menit pada kondisi yang sesuai atau banyaknya enzim yang melepaskan $1 \mu \mathrm{mol}$ gugus gula reduksi per menit pada suhu dan $\mathrm{pH}$ tertentu. 


\section{Elektroforesis SDS-PAGE}

Metode ini dilakukan untuk mengetahui berat molekul protein enzim. Elektroforesis dilakukan dengan sistem discontinous dengan separating gel 12,5\% dan stacking gel 4\%. Running dilakukan pada $10 \mathrm{~mA}$ CC selama 3-4 jam dan menggunakan molekul standar protein (Fermentas).

Gel kemudian dipotong dan direndam dalam larutan staining (coomassie brilliant blue (R-250) selama \pm 30 menit kemudian dibilas dengan larutan destaining sampai pita protein terlihat jelas.

\section{HASIL DAN PEMBAHASAN}

Seleksi isolat uji berdasarkan jumlah $\mathrm{sel} / \mathrm{ml}$. diameter zona jernih ( $\mathrm{mm})$, aktivitas enzim (U/ml), kemampuan dalam klarifikasi jus jeruk dan depolimerisasi pektin cair $1 \%$ maka diperoleh isolat 15, 19 dan 21. Isolat 15 diisolasi dari sampel kulit jeruk pada suhu inkubasi $37^{\circ} \mathrm{C}$. Isolat 19 dan 21 diisolasi dari sampel kulit jeruk dicampur tanah kebun dengan suhu inkubasi masingmasing $50^{\circ} \mathrm{C}$ dan $55^{\circ} \mathrm{C}$ (Widowati, 2012).

Kestabilan enzim berperan dalam preservasi enzim atau dalam aplikasi klarifikasi dan fermentasi produk pangan. Enzim pektik dapat memiliki karakter yang stabil pada kondisi asam atau basa dan pada suhu tertentu sebelum enzim menjadi inaktif. Oleh karena itu, uji ini penting dilakukan supaya enzim bekerja optimal dalam mengkatalis reaksi.

Isolat 15 stabil pada $\mathrm{pH} 3,0-4,0$ dan menjadi inaktif pada $\mathrm{pH} 9,0$ pada suhu $50^{\circ} \mathrm{C}$. Isolat 19 dan 21 stabil pada $\mathrm{pH} 3,0-5,0$ dan inaktif pada $\mathrm{pH} 9,0$ pada suhu $50^{\circ} \mathrm{C}$ (Gambar 1).

Isolat 15,19 dan 21 stabil pada suhu $30-50^{\circ} \mathrm{C}$ kemudian mengalami penurunan aktivitas pada suhu $60^{\circ} \mathrm{C}$ dan inaktif pada suhu $90^{\circ} \mathrm{C}$ pada $\mathrm{pH}$ 7,0 (Gambar 2).

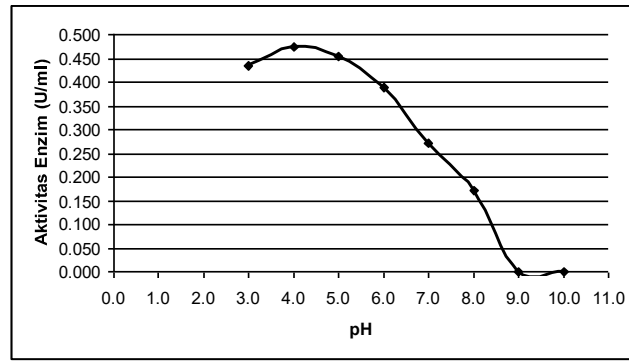

(a)

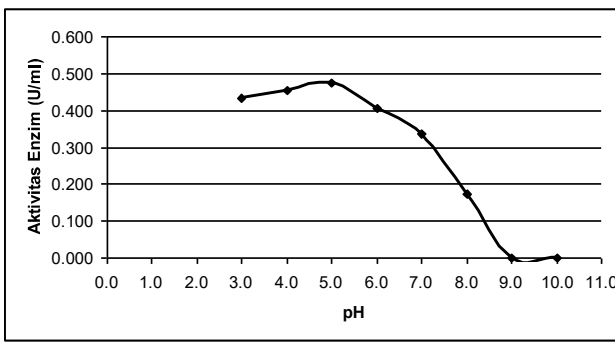

(b)

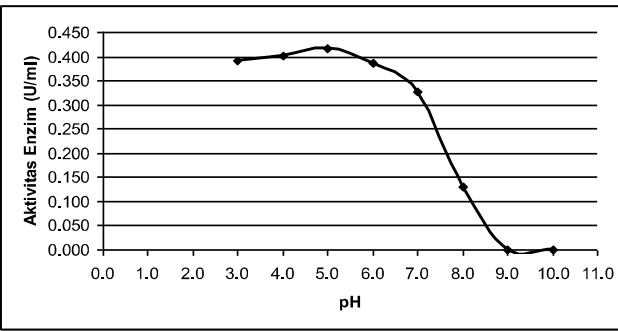

Gambar 1. Kestabilan pH Enzim Isolat 15 (a), 19 (b) dan 21 (c) pada suhu $50^{\circ} \mathrm{C}$

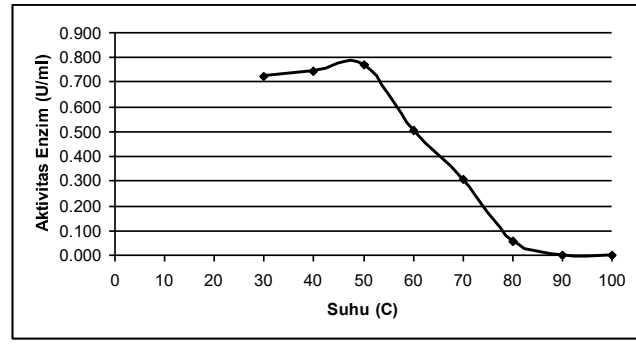

(a)

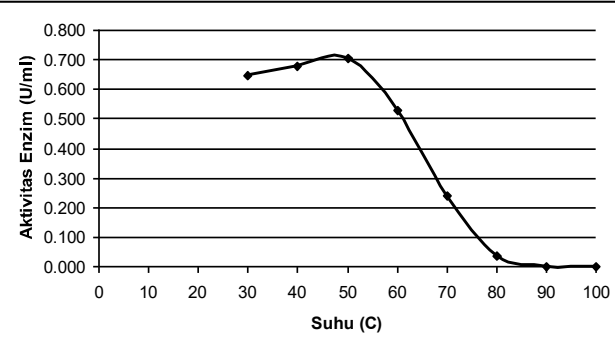

(b)

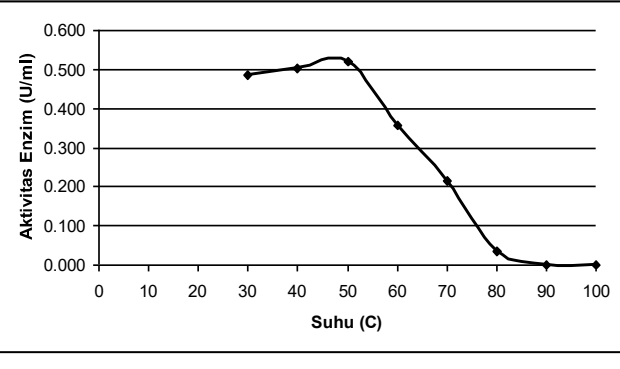

(c)

Gambar 2. Kestabilan Suhu Enzim Isolat 15 (a), 19 (b) dan 21 (c) pada pH 7,0 
Karakterisasi enzim melalui analisis elektroforesis SDS-PAGE diperoleh pita protein pada setiap sampel enzim dari isolat 15,19 dan 21. Enzim isolat 15, 19 dan 21 masing-masing memiliki berat molekul 35,5; 34,5 dan $37,5 \mathrm{kDa}$.

Ketiga sampel diatas dapat dikatakan sebagai enzim yang berbeda karena memiliki profil pita yang berbeda, kondisi $\mathrm{pH}$ optimum dan kestabilan $\mathrm{pH}$ enzim yang berbeda. Enzim pektin hidrolase ekstraseluler diduga merupakan enzim poligalakturonase karena memiliki aktivitas enzim pada $\mathrm{pH} 4,0-5,0$.

Aktivitas enzim endopektinase dapat diketahui dari penurunan viskositas larutan pektin dengan viscometer Ostwald. Satu unit aktivitas enzim didefinisikan sebagai banyaknya enzim yang mereduksi viskositas spesifik dalam larutan (20\% atau 50\%) selama waktu dan suhu tertentu. Aktivitas enzim eksopektinase dapat diketahui berdasarkan pengukuran gula reduksi. Satu unit aktivitas enzim dinyatakan sebagai 1 $\mu$ mol gugus reduksi yang mampu dihidrolisis oleh enzim per menit pada kondisi yang sesuai atau banyaknya enzim yang melepaskan $1 \mu \mathrm{mol}$ gugus gula reduksi per menit pada suhu dan $\mathrm{pH}$ tertentu (Patil and Dayanand, 2006). Berdasarkan pernyataan tersebut maka aktivitas enzim dalam penelitian ini merupakan enzim eksopektinase.

\section{KESIMPULAN}

Kesimpulan dari penelitian ini adalah Enzim pektin hidrolase ekstraseluler isolat 15 stabil pada $\mathrm{pH} 3,0-4,0$ sedangkan enzim pektin hidrolase ekstraseluler isolat 19 dan 21 stabil pada $\mathrm{pH} 3,0-5,0$. Ketiga enzim inaktif pada $\mathrm{pH}$ 9,0 pada suhu inkubasi $50^{\circ} \mathrm{C}$. Enzim pektin hidrolase ekstraseluler isolat 15, 19 dan 21 stabil pada suhu 30$50^{\circ} \mathrm{C}$ kemudian inaktif pada suhu $90^{\circ} \mathrm{C}$ pada pH 7,0. Enzim isolat 15, 19 dan 21 masingmasing memiliki berat molekul 35,5; 34,5 dan $37,5 \mathrm{kDa}$.

\section{Saran}

Penelitian ini memerlukan eksplorasi lebih lanjut mengenai uji kestabilan enzim dengan interval untuk $\mathrm{pH}$ atau suhu terutama dalam aplikasi klarifikasi di skala industri. Selain itu perlu dilakukan eksplorasi lebih lanjut mengenai isolat termostabil.

\section{DAFTAR PUSTAKA}

Benitez, E.I and J.E. Lozano. 2006. Influence of The Soluble Solids on Zeta Potential of a Cloudy Apple Juice, Lat.Am.Appl.Res. Scielo. 36 (3) dalam Widowati, E., Harijono dan A. Sutrisno. 2012. Isolasi dan Karakterisasi Pektin Hidrolase Ektraseluler Bakteri Pektinolitik dalam Klarifikasi Jus Jeruk. Jurnal Teknologi Hasil Pertanian. Volume V No. 2 Agustus 2012: 82-88

Croak, S and M. Corredig. 2006. The Role of Pectin in Orange Juice Stabilization : Effect of Pectin Methyl Esterase and Pectinase Activity on The Size of Cloud Particles. J. Food Hydrocolloids. 20 (7) : 961-965

deCarvalho, L.M.j., R. Borcheta., E.M.M. da Silva., C.W.P. Carvalho., R.M. Miranda and C.A.B. da Silva. 2006. Effect of Enzymatic Hydrolysis on Particle Size Reduction in Lemon Juice (Citrus limon, L.), cv. Tahiti. Braz.J.Food Technol. 9 (4) : 277-282

deMan, J.M. 1997. Kimia Makanan, Edisi Kedua. K. Padmawinata (Penerjemah). Penerbit ITB. Bandung. p. 201-205, 438-446, 457-461, 472

Hidayat, N., M.C. Padaga dan S. Suhartini. 2006. Mikrobiologi Industri, Penerbit Andi. Yogyakarta. p. 10, 35-40, 43-56

Koutchma, T. 2005. Effect of $\mathrm{CO}_{2}$ and Pressure Processing on Microbial and Enzyme inactivation in Food and Beverages. Food Tech International

Laemmli, U.K. 1970. Cleavage of Structural Proteins during The Assembly of The Head of A Bacteriophage T4. $J$. Nature. 227:680-685

Munoz, R and A.B. Ros. 1996. Enzymes in M.L. Leo (Ed.). Handbook of Food Analysis, Volume I. Physical 
Characterization and Nutrient Analysis, Marcel Dekker. New York. $10 \mathrm{p}$

Patil, S.R and A. Dayanand. 2006. Production of Pectinase from Deseeded Sunflower Heed by Aspergillus niger in Submerged and Solid-State Conditions. Biosource Technology. 97 : 2054-2058

Pilnik, W and A.G.J. Voragen. 1993. Pectic Enzymes in Fruit and Vegetable. Juice Manufacture. Enzymes in Food Processing. Academic Press Limited. London. Third Edition. p. 363-392 dalam Widowati, E., Harijono dan A. Sutrisno. 2012. Isolasi dan Karakterisasi Pektin Hidrolase Ektraseluler Bakteri Pektinolitik dalam Klarifikasi Jus Jeruk. Jurnal Teknologi Hasil Pertanian. Volume V No. 2 Agustus 2012 : 82-88

Rolinek, R. 2003. Separation of Three Isoforms of Polygalacturonase from Fermentation Supernatant of Sclerotium rolfsii with Pro Team FFE Compared to Chromatography. http://www.tecan.com/com-pdf. April, 04, 2008 dalam Widowati, E., Harijono dan A. Sutrisno. 2012. Isolasi dan Karakterisasi Pektin Hidrolase Ektraseluler Bakteri Pektinolitik dalam Klarifikasi Jus Jeruk. Jurnal Teknologi Hasil Pertanian. Volume V No. 2 Agustus $2012: 82-88$

Salvador, L.D., T. Singanuma., K. Kitahara., Y. Fukusage and H. Tanoue. 2002. Degradation of Cell Wall Materials from Sweet Potato, Cassava and Potato by A Bacterial Protopectinase and Terminal Sugar Analysis of The Resulting Solubilized Products, Journal of Bioscience and Bioengineering. 93 (1) : 64-72 dalam Widowati, E., Harijono dan A. Sutrisno. 2012. Isolasi dan Karakterisasi Pektin Hidrolase Ektraseluler Bakteri Pektinolitik dalam Klarifikasi Jus Jeruk. Jurnal Teknologi Hasil Pertanian. Volume V No. 2 Agustus 2012: 82-88
Van Rijssel, M., G.J. Gerwig and T.A. Hansen. 1993. Isolation and Characterization of an Extracellular Glycosylated Protein Complex from Clostridium thermosaccharolyticum with Polygalacturonase and Pectin Methyl Esterase Hydrolase Activity, $J$. Applied and Enviromental Microbiology. 59 (3) : 828-836

Widowati, E., Harijono dan A. Sutrisno. 2012. Isolasi dan Karakterisasi Pektin Hidrolase Ektraseluler Bakteri Pektinolitik dalam Klarifikasi Jus Jeruk. Jurnal Teknologi Hasil Pertanian. Volume V No. 2 Agustus 2012: 82-88

Wilson, K and J. Walker. 2004. Principles and Techniques of Practical Biochemistry. Fourth Edition. Cambridge University Press. Cambridge. $15 \mathrm{p}$ 